\title{
The volumetric potential assessment of the oil shales of Tremembé Formation, Taubaté Basin, Brazil
}

\author{
Fernanda Setta ${ }^{1} \cdot$ Sérgio Bergamaschi $^{1} \cdot$ René Rodrigues $^{1} \cdot$ Cleveland Jones $^{1} \cdot$ Hernani Chaves $^{1} \cdot$ Marco Brito $^{1}$. \\ Egberto Pereira ${ }^{1}$
}

Received: 17 September 2019 / Accepted: 28 January 2020 / Published online: 24 February 2020

(c) The Author(s) 2020

\begin{abstract}
This assessment of the volumetric potential of the oil shales of Tremembé Formation (Oligocene, Taubaté Basin, Brazil) was based on the sedimentological study of 2457 total organic carbon and 1007 Rock-Eval pyrolysis analyses of core samples from nine survey wells drilled in the central portion of Taubate Basin. Along a 240-m-thick package in the upper part of Tremembé Formation, thirteen chemostratigraphic units with thicknesses varying from 10 to $35 \mathrm{~m}$ were identified. The upper interval (unit L), $30 \mathrm{~m}$ thick, exhibited the highest organic content and original generation potential and was thus studied in detail. In unit L, oil yield maps were constructed, seeking to identify the most attractive areas for industrially exploiting the oil shales, and volumetric calculations employing a probabilistic Monte Carlo method were conducted to quantify the potentially recoverable oil volume. Three exploratory scenarios based on yield values $(\mathrm{S} 1+\mathrm{S} 2)$ were considered for calculating the oil volumes, seeking to offer different exploratory scenarios for decision making. For the scenario that considered only average yields above $100 \mathrm{mg} \mathrm{HC/g}$ rock, the recoverable oil volume is 525 million bbl (P90) to 884 million bbl (P10); for the scenario that considered only average yields above $80 \mathrm{mg} \mathrm{HC} / \mathrm{g}$ rock, the recoverable oil volume is 1.4 billion bbl (P90) to 2.6 billion bbl (P10); and for the scenario that considered only average yields above $60 \mathrm{mg} \mathrm{HC/g}$ rock, the recoverable oil volume is 3.6 billion bbl (P90) to 5.4 billion bbl (P10).
\end{abstract}

Keywords Organic geochemistry $\cdot$ Chemical stratigraphy $\cdot$ Area yields $\cdot$ Volume calculation $\cdot$ Monte Carlo method

\section{Introduction}

Fernanda Setta

fernandasetta@gmail.com

Sérgio Bergamaschi

sergioberg7@hotmail.com

René Rodrigues

rene.rodrigues.uerj@gmail.com

Cleveland Jones

clevelandmjones@gmail.com

Hernani Chaves

hfchaves@gmail.com

Marco Brito

castro.marco@hotmail.com

Egberto Pereira

egberto.geologia@gmail.com

1 Faculdade de Geologia, Departamento de Estratigrafia e Paleontologia, Universidade do Estado do Rio de Janeiro, Rua São Francisco Xavier, 524, Rio de Janeiro 20550-013, Brazil
Brazil has an enormous potential for unconventional resources to be explored in the different sedimentary basins within its territory, and in particular, its oil shales. Among the unconventional hydrocarbon resources in Brazil, those related to the oil shales of the Tremembé Formation in Taubaté Basin, in São Paulo state (Fig. 1), have historically attracted the greatest attention regarding their economic recovery potential (e.g., Abreu 1936; Padula 1969; Dyni 2006). These resources were industrially exploited until the mid-1900s, by the extinct Conselho Nacional de Petróleo (CNP-National Petroleum Council), through an extraction plant in Pindamonhangaba, SP, with a processing capacity of up to 10 thousand barrels per day (Milani and Araújo 2003). Technological limitations and management decisions by Petrobras, recently created at that time, led to the decommissioning of that oil extraction plant. However, in the last 10 years, that situation has been quickly changing in a positive fashion. 


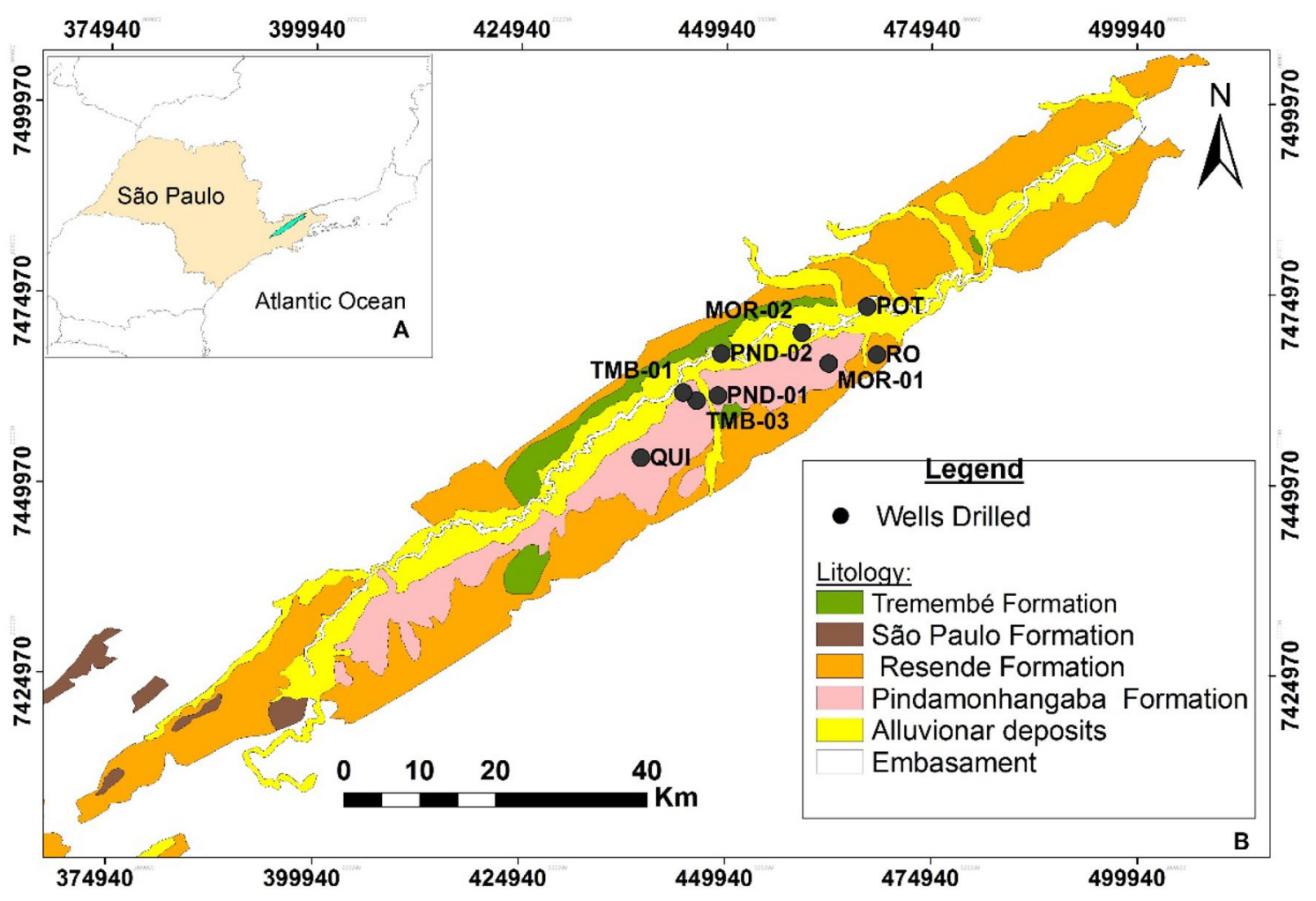

Fig. 1 a Map showing the location of the Taubaté Basin. b Simplified geological map of Taubaté Basin, showing the wells studied Source modified from Riccomini 2004

The determination of the quantity, quality and maturation of the organic matter is parameters utilized in assessing the generation potential and the economic attractiveness of unconventional resources.

With the exception of unpublished reports, updated geochemical data that cover the mid- and upper sections of the Tremembé Formation are not available in the literature, at this time. Thus, the present study sought to assess the quantity and quality of the organic matter present in Tremembé Formation, employing TOC and Rock-Eval pyrolysis analyses. Based on those data, a chemostratigraphic sectioning of this unit was proposed, as well as a geochemical correlation of the subunits among the studied wells. Maps showing the distribution of the generation potential (S2) of the most promising intervals were also constructed, seeking to characterize the best region for possible economic exploitation of the oil shales. Finally, a volumetric assessment of hydrocarbons (in bbl), under three different exploration scenarios, was made for the chemostratigraphic subunits considered to be the most important.

\section{Geological setting of Taubaté Basin}

The Taubate Basin is located between the Mantiqueira Range and the Serra do Mar range, in Paraíba valley, in eastern São Paulo state, Brazil. Taubaté Basin is part of a set of Cenozoic Tafrogenic Basins and is elongated along the ENE direction, approximately $170 \mathrm{~km}$ long and $20 \mathrm{~km}$ wide. Its average sedimentary thickness is $500 \mathrm{~m}$, reaching a maximum thickness of $800 \mathrm{~m}$ (Fernandes 1993). Its elongated and oriented shape follows the main tectonic-structural traces (framework) of the crystalline basement in the southeastern region of Brazil.

Taubaté Basin is classified as an intracontinental rift basin, due to its structural elements, such as predominance of normal faults, asymmetric compartments in section and plan view, and faults with inversion of rotational direction (Fernandes 1993). 
According to Riccomini (1989), its fill history can be divided into two phases. The first phase, syntectonic with rifting, corresponds to a distensive phase, in which alluvial and lacustrine sediments of the Taubaté Group were deposited during the Paleogene. In the second phase, after diastrophic tectonism, fluvial sediments of the Pindamonhangaba Formation and alluvial and colluvial Quaternary sediments were deposited (Fig. 2).

As conceived by Riccomini (1989), the Taubaté Group is composed of the Resende, Tremembé and São Paulo formations.

The Tremembé Formation is situated in the intermediary portion of Taubaté Group, being composed of sediments associated with a lacustrine system, represented by massive green argillites, shales rhythmites and marls, dolomites and sandstones. Riccomini (1989) interprets Tremembé Formation as a lacustrine system of the playa-lake type. This system is better developed in the central portion of Taubaté Basin, and to a lesser extent, in São Paulo Basin, both of which are part of the Continental Rift of Southeast Brazil (CRSB). The maximum thickness attained in this unit is approximately $400 \mathrm{~m}$ (Sampol 2007).

This formation always raised academic and economic interest, which resulted in numerous studies regarding various paleontological, stratigraphic, tectonic, geophysical, geochemical and economic aspects (e.g., Suguio 1969; Mezzalira 1989; Riccomini 1989; Marques 1990; Padilha et al. 1991; Fernandes 1993; Riccomini et al. 2004; Torres-Ribeiro 2004; Zalán and Oliveira 2005; Freitas 2007; Torres-Ribeiro and Borghi 2007; Chagas et al. 2009; Duarte 2012). This formation is widely known for its rich and diversified fossiliferous content, including references to remains of leaves, angiosperm tree trunks, sponge spicules, wormholes, gastropods, ostracods, crustaceans, insects (Lepidoptera), fishes, birds, reptiles (crocodilians and chelonians) and mammals (Chiroptera, Toxodontidae, Rodentia) (Mezzalira 1989). The pollen content of samples from Tremembé Formation, intercepted by CNP well \#42, led Lima et al. (1985) to suggest an oligogenic age for this unit. According to Mendonça Filho et al. (2010) and Chagas et al. (2009), the bituminous shales with high organic carbon content and high $\mathrm{S} 2$ and $\mathrm{HI}$ are predominantly composed of amorphous organic matter or fresh water microplankton.
Fig. 2 Lithostratigraphic chart of Taubaté Basin. Also illustrated are its tectonic phases Source Riccomini et al. (2004)

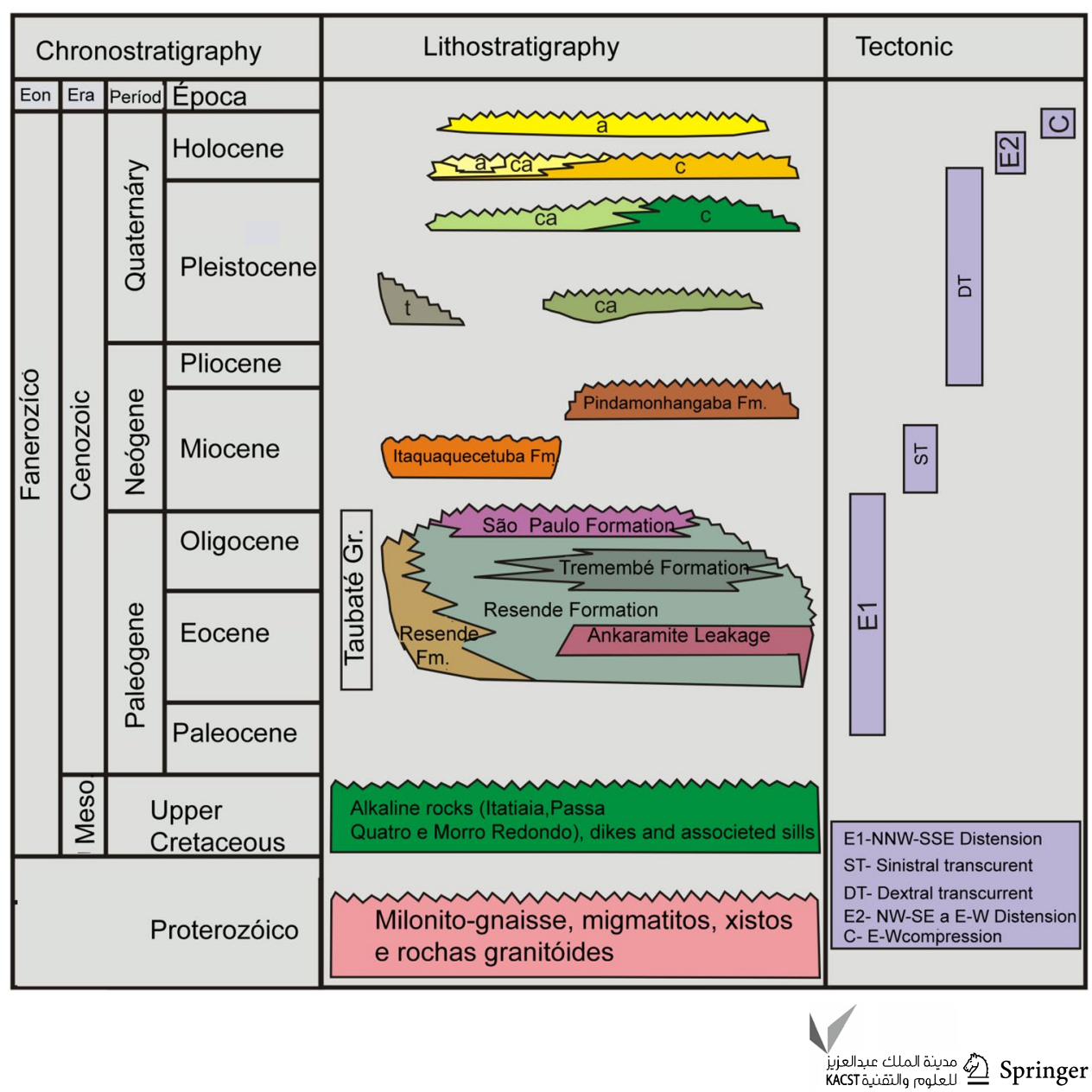


Table 1 Information regarding the wells studied

\begin{tabular}{lllllll}
\hline Wells & Location & & $\begin{array}{l}\text { Elevation of } \\
\text { the well }(\mathrm{m})\end{array}$ & Final depth $(\mathrm{m})$ & $\begin{array}{l}\text { Total } \\
\text { samples for } \\
\text { TOC }\end{array}$ & $\begin{array}{l}\text { Total samples } \\
\text { for Rock-Eval } \\
\text { pyrolysis }\end{array}$ \\
\hline TMB-03-SP & x: 446347 & y:7461042 & 565 & 240 & 627 & 362 \\
POT-01-SP & x: 467070 & y:7473429 & 532 & 100 & 394 & 80 \\
PND-02-SP & x: 449312 & y:7462094 & 537 & 80 & 230 & 139 \\
MOR-02-SP & x: 459163 & y:7469999 & 531 & 80 & 288 & 153 \\
TMB-01-SP & x: 444704 & y:7462094 & 549 & 55 & 207 & 86 \\
PND-01-SP & x: 448938 & y:7461699 & 567 & 53 & 162 & 57 \\
MOR-01-SP & x: 462388 & y:7465951 & 561 & 55 & 180 & 79 \\
RO-01-SP & x: 468250 & y:7467128 & 558 & 55 & 194 & 0 \\
QUI-01-SP & x: 439603 & y:7453490 & 573 & 55 & 175 & 51 \\
\hline
\end{tabular}

\section{Materials and methods}

Samples were analyzed from nine shallow wells (varying from 53 to $241 \mathrm{~m}$ deep) (Table 1), which were drilled with a rotary rig owned by the State University of Rio de Janeiro (UERJ), in locations shown in Fig. 1.

From all the wells analyzed, approximately $650 \mathrm{~m}$ of cores was recovered. These cores were sedimentologically described, and the faciological characteristics of the section were emphasized, in terms of its main attributes, such as lithology, color, structure and fossils. The sampling for geochemical analyses followed an average spacing of $20 \mathrm{~cm}$, which occasionally varied, due to the faciological characteristics of the deposits. A total of 2457 samples were collected for determination of TOC, sulfur and insoluble residue. Based on the TOC results, 1007 samples were selected for Rock-Eval pyrolysis analyses. These analyses, as well as pycnometry, were performed by Laboratório de Estratigrafia Química e Geoquímica Orgânica_LGQM (Chemical Stratigraphy and Organic Geochemistry Laboratory) of the Faculty of Geology (FGEL) of UERJ. The distribution of the samples according to the well from which they came can be seen in Table 1.

\section{Total organic carbon (TOC)}

The rock samples were ground, weighed, decalcified and weighed again ( $\mathrm{RI}=$ insoluble residue data). Then, they were analyzed in a Leco SC-632, with the TOC values reported as \% relative to the weight of the original sample. Part of the samples that exhibited TOC values equal or greater than $0.5 \%$ were selected for pyrolysis analyses.

\section{Rock-Eval pyrolysis}

The samples were weighed and then analyzed in a Rock-Eval 6 pyrolyzer from Vinci Technologies, following the procedures indicated by Espistalié et al. (1985). The following parameters were read: S1 (in milligrams of hydrocarbons per gram of rock-mg HC/g rock), S2 (in $\mathrm{mg} \mathrm{HC/g}$ rock), S3 (in $\mathrm{mg} \mathrm{CO}_{2} / \mathrm{g}$ rock) and temperature at which the peak in $\mathrm{S} 2$ occurs $\left(\mathrm{Tmax}\right.$, in $\left.{ }^{\circ} \mathrm{C}\right)$.

The pyrolysis data, together with the TOC data, allowed the calculation of the hydrogen index $(\mathrm{HI}=\mathrm{S} 2 / \mathrm{TOC} \times 100)$ and the oxygen index $(\mathrm{OI}=\mathrm{S} 3 / \mathrm{TOC} \times 100)$.

\section{Density}

In order to measure the density of Tremembé shales, different methods were employed: volume calculation with a caliper, pycnometry, fluid displacement and gas pycnometer. Considering the lower costs involved, and faster and more practical operation, density assays were performed by pycnometry, according to the procedures described by Silva 2007. In this study, a 25-ml pycnometer was utilized.

To determine the average density of the oil shales from the most promising intervals, samples from well TMB03-SP were utilized, which was drilled next to the area with the highest organic content in the basin. Then, 19 samples were selected, with different degrees organic enrichment. Since oil shales are rocks that can hold water in their matrix, it was necessary to submerge the samples in resin in order to seal the material. The densities of the samples were calculated based on the equation described in Silva 2007.

\section{Volume}

Probabilistic simulations describe techniques that reach approximate solutions to quantitative problems, via random sampling from a universe of possible solutions. The Monte Carlo method (also known as Monte Carlo simulation) explicitly represents the uncertainties of a problem, specifying input variables with a given probability distribution, and then performs numerous calculations to find a set of deterministic solutions, based on random sampling of the values for the input variables (Jones 2009). 
The Monte Carlo method was utilized to calculate the rock volume and volume of the oil that could be recovered from the Tremembé Formation, based on available input parameters. A probabilistic calculation tool was utilized: the "Probabilistic Assessment Tool Using Monte Carlo Method," version 2.1, which works within a spreadsheet in Microsoft Excel@ (Microsoft Office 2013 package).

Seeking to offer different exploratory scenarios for decision making, depending on distinct technological and/or economic factors, three scenarios were considered for the volume calculation. These scenarios are based on distinct values for the yield from the oil shales (cutoff values). In the first scenario, only areas limited by a cutoff yield greater than $100 \mathrm{mg} \mathrm{HC} / \mathrm{g}$ rock were considered. In the second scenario, the possibility of economic viability of areas with an intermediary cutoff yield of $80 \mathrm{mg} \mathrm{HC/g}$ rock is considered. In the third scenario, economic viability of areas with a cutoff yield of $60 \mathrm{mg} \mathrm{HC/g}$ rock is considered. These values were chosen considering that the maximum yield found for the different units was $100 \mathrm{mg} \mathrm{HC/g}$ rock, and that the average of the different units was $69 \mathrm{mg} \mathrm{HC/g}$ rock. Thus, the maximum yield (100 mg HC/g rock) was utilized for the first scenario, a value slightly lower than the average ( $60 \mathrm{mg} \mathrm{HC/g}$ rock) was utilized in the third scenario, and an average of those two values $(80 \mathrm{mg} \mathrm{HC} / \mathrm{g}$ rock) was utilized for the second scenario.

It is worth noting that probabilistic results are presented for each scenario, with confidence levels of P90, P50 and $\mathrm{P} 10$. These confidence levels correspond to $1 \mathrm{P}$ or proven reserves (90\% chance that the actual recoverable amount is equal or greater than the value indicated), $2 \mathrm{P}$ or proven plus probable reserves $(50 \%$ chance that the actual recoverable amount is equal or greater than the value indicated) and $3 \mathrm{P}$ or proven plus probable plus possible reserves $(10 \%$ chance that the actual recoverable amount is equal or greater than the value indicated), respectively (SPE-PRMS 2007).

The input variables for the volumetric calculation employing the Monte Carlo method are the following: average thickness $(\mathrm{m})$, average area $\left(\mathrm{km}^{2}\right)$, average rock density $\left(\mathrm{g} / \mathrm{m}^{3}\right)$, average yield $(\mathrm{S} 1+\mathrm{S} 2, \mathrm{mg} \mathrm{HC} / \mathrm{g}$ rock), average conversion factor of rock to oil and their respective standard deviations. The total volume of recoverable oil is obtained by multiplying together all these variables.

The areas in each subunit were obtained based on the polygon of the 60,80 or $100 \mathrm{mg} \mathrm{HC/g}$ rock isoline. Thus,

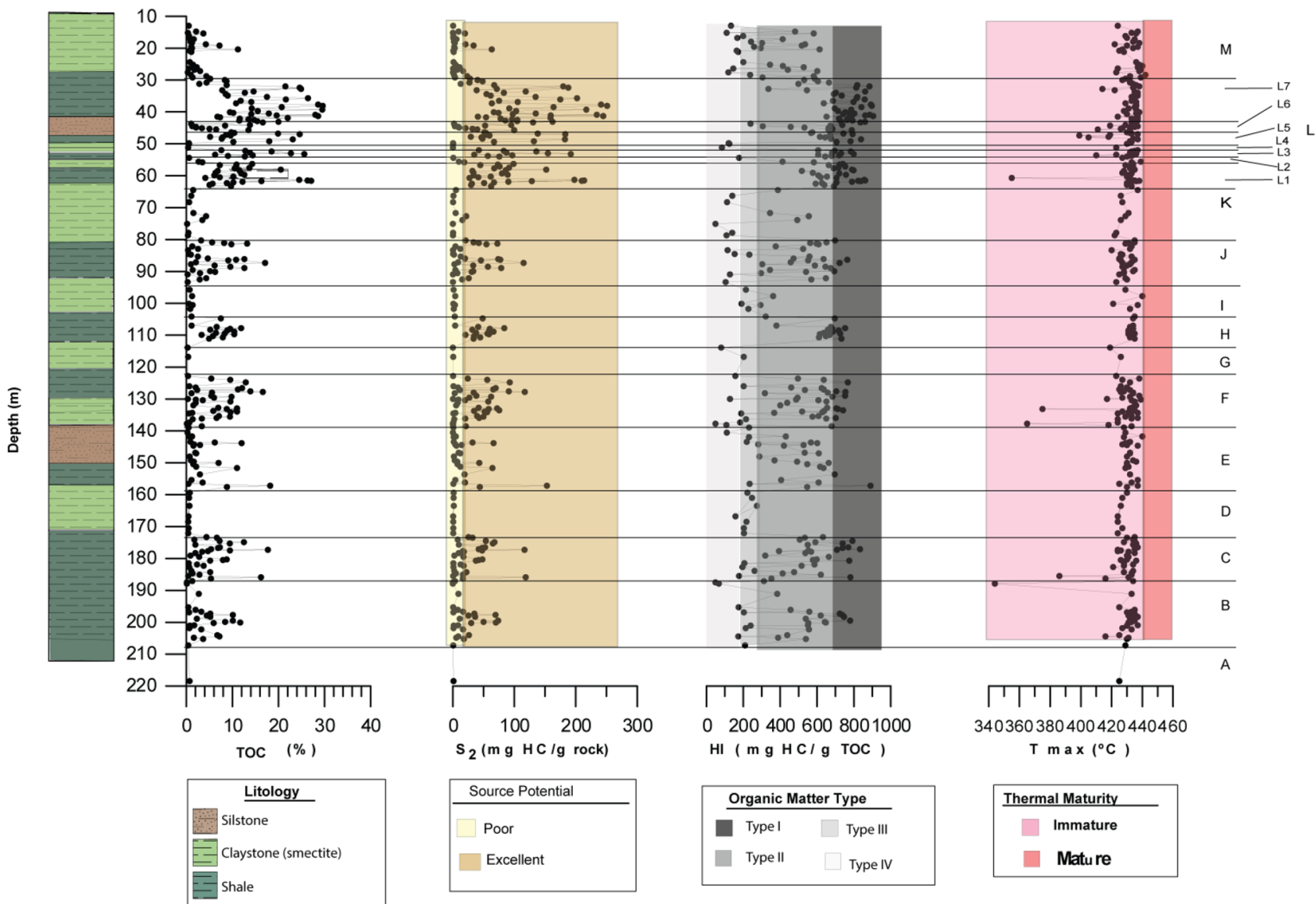

Fig. 3 TOC, S2, HI and Tmax in well TMB-03-SP in Tremembé Formation 
in each scenario, the areas of the respective isolines varied according to the distribution of the occurrence of the average yield. These maps were constructed with Geosoft Oasis Montaj version 6.4.2.

The average thickness of each subunit was obtained based on the top and base of the chemostratigraphic units of economic interest, as defined in each of the wells considered in the volume calculation.

The average density value adopted represents an average of the values obtained for the shale samples with high yields. This value is comparable to those adopted by other authors cited, such as Campos (1952), who adopted an average density of $1.6 \mathrm{~g} / \mathrm{cm}^{3}$, and Castro and Silva (1952), who adopted an average density of $1.4 \mathrm{~g} / \mathrm{cm}^{3}$. As to the value for the conversion factor, a value of 0.9 was used, based on the study of Soldan et al. (1988).

\section{Results and discussion}

In the nine wells studied, data from TOC, sulfur, RI and Rock-Eval pyrolysis were integrated. To illustrate the vertical distribution of the TOC and the Rock-Eval pyrolysis values in the upper section of the Tremembe Formation, the
TMB-3-SP well (Fig. 3) was utilized as an example, since among all wells, it penetrated the thickest section of Tremembé Formation $(240 \mathrm{~m})$. The Tmax values show that the organic matter of Tremembé Formation is thermally immature in well TMB-03-SP (Fig. 3). As with the Tremembé Formation, the organic matter in that entire area is thermally immature (Bergamashi et al. 2010; Mendonça Filho et al. 2010). That is due to the thinness of the total sedimentary package of the Taubaté Graben (Marques 1990).

Based on TOC, S2 and HI data, the section of well TMB3-SP was subdivided into 13 chemostratigraphic units, informally named A to M (Fig. 3). Unit L is the interval with the highest organic matter enrichment in Tremembé Formation; thus, it raises the greatest interest, from the point of view of hydrocarbon generation. Given this potential, a more thorough analysis was performed, in order to characterize the interval in greater detail.

Based on the TOC values, it was possible to identify seven chemostratigraphic subunits in the section of unit $\mathrm{L}$, informally named L1 to L7, from the base to the top. The correlation of these subunits among the wells is presented in sections A-A' and B-B', whose stratigraphic datum utilized was the top of the first layer of smectitic argillite (Figs. 4 and 5). In the correlation sections, subunits L2 and L4,

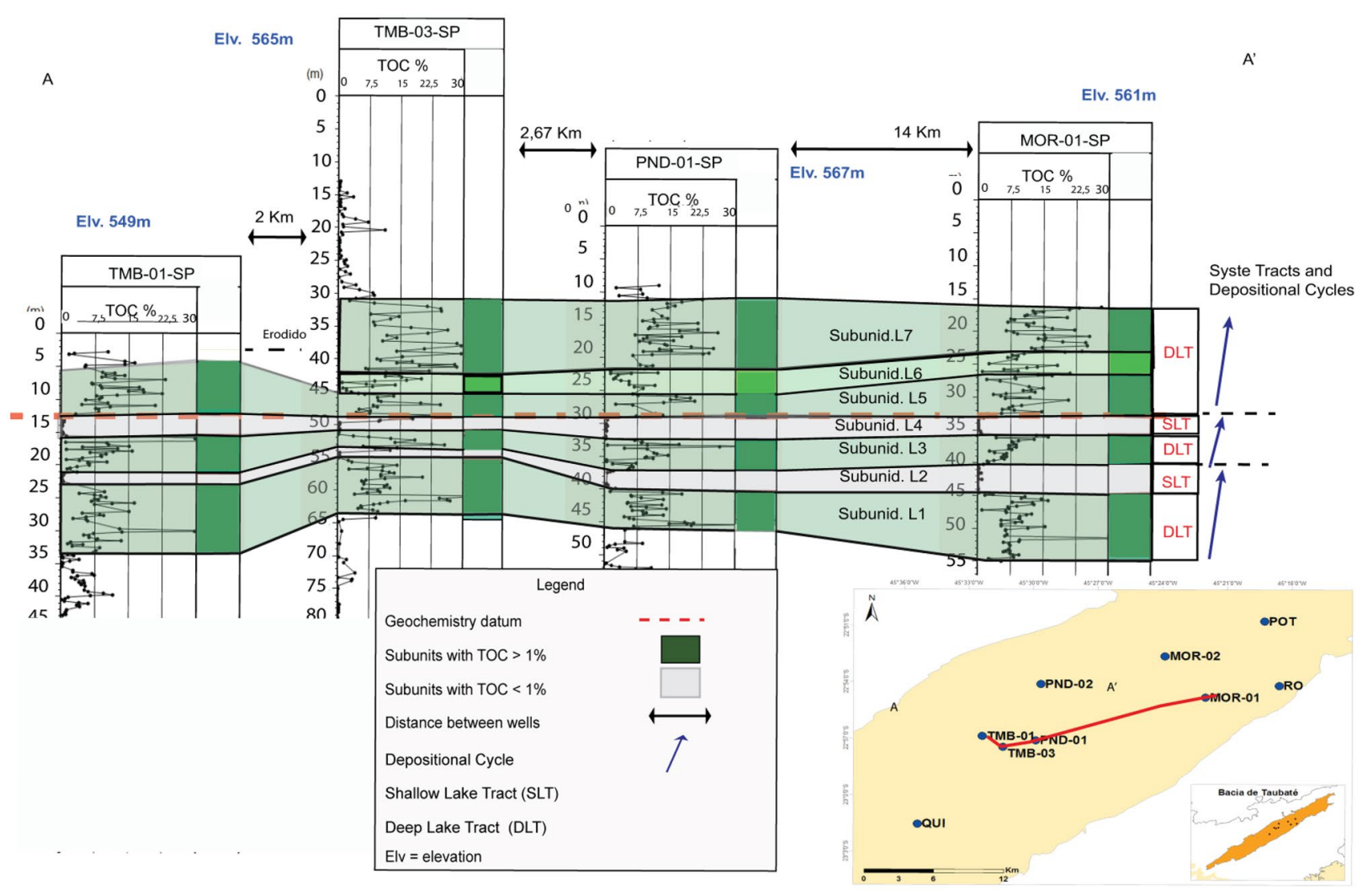

Fig. 4 Correlation A-A' between wells TMB-01-SP, TMB-03-SP, PND-02-SP and MOR-01-SP, based on TOC data 
characterized by the red color in Figs. 4 and 5, are associated with the smectitic argillite intervals normally identified by their low TOC $(<1 \%)$ values. Subunits L1, L3, L5, L6 and L7 are characterized by elevated average values of TOC, varying from 3 to $16 \%$ (Table 2). These subunits are discussed in greater detail later in this work, considering their greater organic matter enrichment.

Considering that the organic matter is thermally immature, the S2 and HI values are the original values, which permits assessing their generation potential. In units L1, L3, L5, L6 and L7, values of S2 above $10 \mathrm{mg} \mathrm{HC/g}$ rock and $\mathrm{HI}$ values between 400 and $850 \mathrm{mg} \mathrm{HC/g}$ TOC indicate an excellent potential for oil generation. In units L2 and L4, values of $\mathrm{S} 2$ below $10 \mathrm{mg} \mathrm{HC/g}$ rock and $\mathrm{HI}$ values below $200 \mathrm{mg} \mathrm{HC} / \mathrm{g}$ TOC indicate a poor to good generation potential for gas.

As to the types of organic matter, as shown in the van Krevelen diagram (Fig. 6), units L1, L3, L5, L6 and L7 are composed of Type I to Type II organic matter, and units L2 and L4 are composed, respectively, of Type III and Type IV organic matter. The different types of kerogen are due to the fact that units L1, L3, L5, L6 and L7 are composed of shales deposited in an anoxic environment, corresponding to deep lake depositional phases, while units L2 and L4 are composed of smectitic argillites deposited in an oxic environment, corresponding to shallow lake depositional phases (Riccomini et al. 2004; Torres-Ribeiro and Borghi 2007; Bergamaschi et al. 2010; Setta et al. 2012).

The minimum parameters required for assessing oil shale potential vary according to the geology and legislation of each country (BYNI 2006). In the case of Brazil, the sole production reference is the PetroSix operation of Petrobras, which extracts oil from the black shales of Irati Formation (Padula 1969; Milani et al. 2007). In the two intervals exploited, the shales are thermally immature and exhibit average values of TOC above $10 \%$, average values of $\mathrm{HI}$ of $600 \mathrm{mg} \mathrm{HC} / \mathrm{g}$ TOC, depth of up to $60 \mathrm{~m}$ and thicknesses of 3 to $6.5 \mathrm{~m}$ (Milani et al. 2007). As can be seen in Table 3, units L1, L3, L5, L6 and L7 are potentially attractive for industrial production of oil shale since they contain thermally immature $\left(\operatorname{Tmax}<440{ }^{\circ} \mathrm{C}\right)$ black shales with high TOC average content (from $7 \%$ to $13 \%$ ), good organic matter quality (average values of $\mathrm{HI}$ from 484 to $641 \mathrm{mg} / \mathrm{g}$ ), which are close to the surface (depths from 10 to $65 \mathrm{~m}$ ) and have thicknesses of 2 to $9 \mathrm{~m}$, with average total net thickness of $31 \mathrm{~m}$.

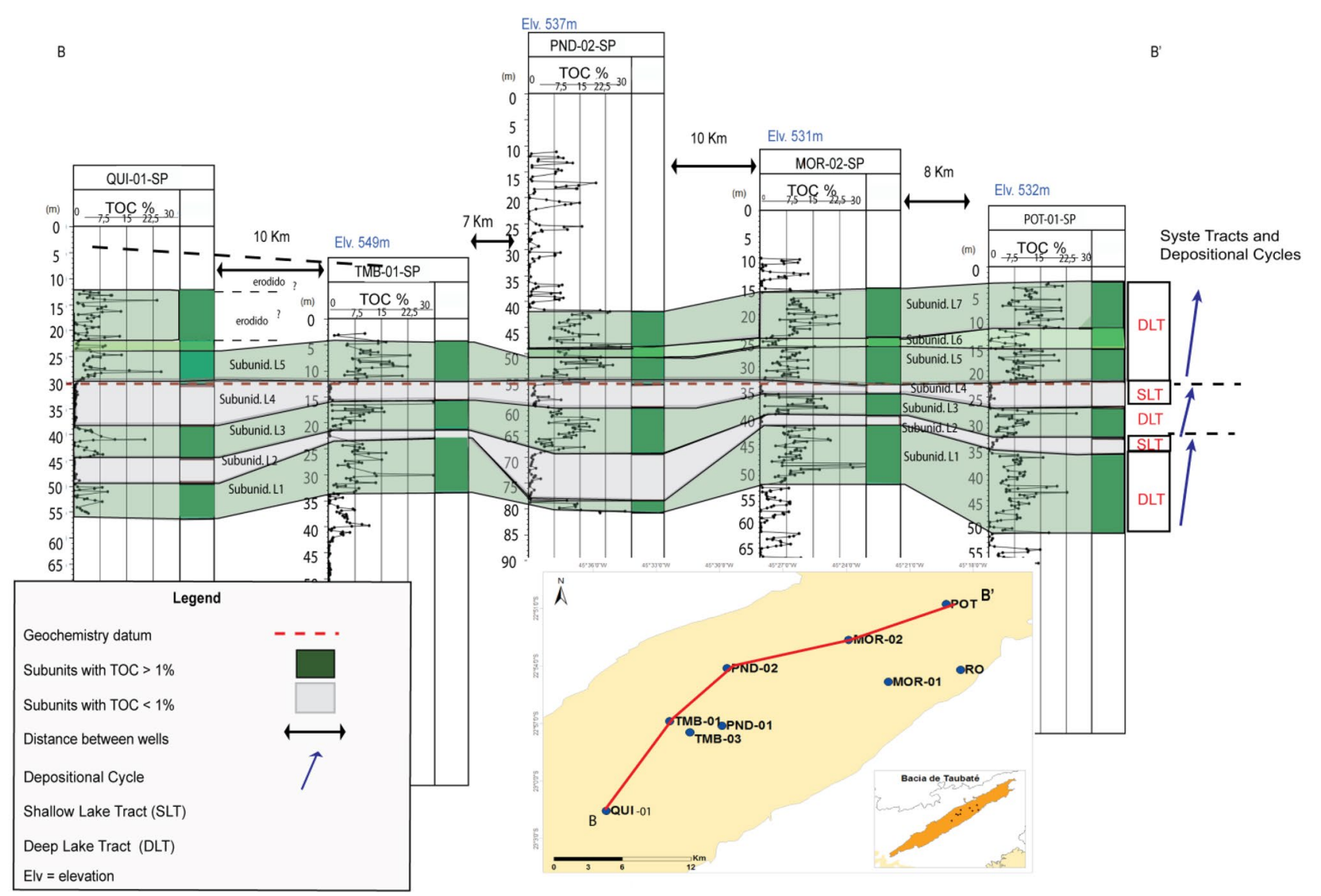

Fig. 5 Correlation B-B' between wells QUI-SP, TMB-01-SP, PND-02-SP, MOR-02-SP and POT-01-SP, based on TOC data 
Table 2 Thicknesses of chemostratigraphic subunits L1, L3, L5, L6 and L7, and respective average values of TOC (in \%), yield (S1 + S2 in mg $\mathrm{HC} / \mathrm{g}$ rock) and $\mathrm{HI}$ (in $\mathrm{mg} \mathrm{HC/g}$ TOC). $\mathrm{x}$-absent units. $\mathrm{y}$-well did not completely penetrate the unit

\begin{tabular}{|c|c|c|c|c|c|c|c|c|c|}
\hline \multirow[t]{2}{*}{ Subunit } & \multirow[t]{2}{*}{ Data } & \multicolumn{8}{|l|}{ Wells } \\
\hline & & QUI-SP & TMB01-SP & TMB03-SP & PND01-SP & PND02-SP & MOR02-SP & MOR01-SP & POT01-SP \\
\hline \multirow[t]{4}{*}{ L7 } & Thickness (m) & 8 & $\mathrm{x}$ & 12 & 11 & 7 & 9 & 7 & 11 \\
\hline & TOC & 5.14 & $\mathrm{x}$ & 15.63 & 12.95 & 14 & 12.51 & 15.67 & 13.15 \\
\hline & $\mathrm{S} 1+\mathrm{S} 2$ & 52.5 & $\mathrm{x}$ & 118.98 & 104.1 & 119.19 & 87.89 & 119.1 & 89.34 \\
\hline & $\mathrm{IH}$ & 544.92 & $\mathrm{x}$ & 691.47 & 649 & 721.66 & 591.33 & 678.98 & 612.57 \\
\hline \multirow[t]{4}{*}{ L6 } & Thickness & 2 & $\mathrm{x}$ & 3 & 4 & $\mathrm{x}$ & 2 & 3 & 2 \\
\hline & TOC & 5.56 & $\mathrm{x}$ & 9.47 & 5.56 & $\mathrm{x}$ & 3.02 & 8.85 & 5.53 \\
\hline & $\mathrm{S} 1+\mathrm{S} 2$ & 18.65 & $\mathrm{x}$ & 30.82 & 19.92 & $\mathrm{x}$ & 19.3 & 81.61 & 18.3 \\
\hline & $\mathrm{IH}$ & 320.31 & $\mathrm{x}$ & 615.38 & 533.5 & $\mathrm{x}$ & 471.17 & 593.78 & 370 \\
\hline \multirow[t]{4}{*}{ L5 } & Thickness & 7 & 8 & 4 & 4 & 8 & 7 & 6 & 6 \\
\hline & TOC & 5.85 & 11.11 & 12.28 & 11.89 & 14.12 & 8.72 & 9.02 & 8.99 \\
\hline & $\mathrm{S} 1+\mathrm{S} 2$ & 55.53 & 93.15 & 83.83 & 44.07 & 124.2 & 49.4 & 80.65 & 69.14 \\
\hline & $\mathrm{IH}$ & 615.06 & 649.48 & 648.49 & 555.1 & 750.24 & 515.8 & 659.19 & 591.92 \\
\hline \multirow[t]{4}{*}{ L3 } & Thickness & 5 & 5 & 2 & 5 & 10 & 2 & 4 & 6 \\
\hline & TOC & 5.41 & 9.61 & 13.39 & 9.27 & 10.23 & 10.43 & 7.03 & 7.03 \\
\hline & $\mathrm{S} 1+\mathrm{S} 2$ & 54.96 & 89.1 & 98.06 & 63.71 & 77.33 & 77.1 & 50.91 & 50 \\
\hline & $\mathrm{IH}$ & 568 & 636 & 645 & 586 & 631 & 504 & 609 & 546 \\
\hline \multirow[t]{4}{*}{ L1 } & Thickness & 5 & 10 & 9 & 6 & $\mathrm{y}$ & 10 & 10 & 15 \\
\hline & TOC & 3.63 & 8.71 & 11.38 & 10.83 & $\mathrm{y}$ & 10.84 & 9.39 & 8.03 \\
\hline & $\mathrm{S} 1+\mathrm{S} 2$ & 30 & 77.49 & 85 & 68.13 & $\mathrm{y}$ & 84.29 & 58.04 & 54.43 \\
\hline & $\mathrm{IH}$ & 477 & 661 & 660 & 557 & $\mathrm{y}$ & 642 & 585 & 540 \\
\hline
\end{tabular}

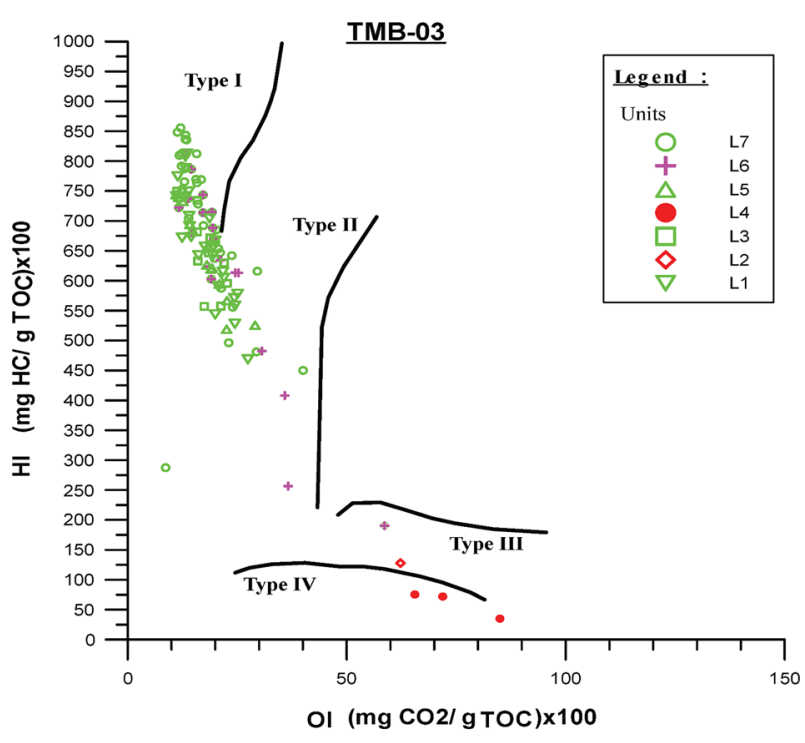

Fig. 6 van Krevelen diagram showing the different types of organic matter for the studied units

Maps of average TOC values were constructed for subunits L1, L3, L5, L6 and L7, in order to show the regions with greatest organic matter enrichment (Fig. 7). However, in unit L1, at well PND-02-SP, TOC data, as well as $\mathrm{S} 1+\mathrm{S} 2$, were not considered in constructing the maps, since in that location unit $\mathrm{L} 1$ is not complete.

Hydrocarbon yield maps for subunits L1, L3, L5, L6 and L7 (Fig. 8) summarize the distribution of the average yields (in $\mathrm{mg} \mathrm{HC/g} \mathrm{rock)} \mathrm{of} \mathrm{S1}+\mathrm{S} 2$ for each well (Table 2), indicating areas potentially more favorable from an economic point of view. In constructing these maps, arbitrary yield values near zero were considered next to the edges of the basin. This premise was adopted considering the predominance of sandy facies in these areas, as shown by Vidal et al. (2004).

Figure 8 shows the chemostratigraphic units and the isolines for yields of 60,80 and $100 \mathrm{mg} \mathrm{HC} / \mathrm{g}$ rock (red). It can be observed that the isolines of greatest yield $(100 \mathrm{mg}$ $\mathrm{HC} / \mathrm{g}$ ) surround wells TMB-03-SP and PND-02-SP, in most of the seven subunits, thus representing the area of greatest potential.

\section{Volumetric calculation considering a yield cutoff of $100 \mathrm{mg} \mathrm{HC} / \mathrm{g}$ rock}

Initially, a high cutoff yield was considered (average yield greater than $100 \mathrm{mg} \mathrm{HC/g}$ rock), seeking to establish a parameter for an exploratory scenario that is more restricted in terms of area and yield. This represents a conservative scenario (Fig. 9). 
Table 3 Dados de quantidade (COT), qualidade (IH), maturação (Tmax),

profundidade, espessura, litologia para as unidades de maior interesse para recusrso de oil shale

\begin{tabular}{llllll}
\hline & L1 & L3 & L5 & L6 & L7 \\
\hline TOC $(\%)$ & 10 & 9 & 10 & 7 & 13 \\
IH (mg HC/g TOC) & 600 & 559 & 622 & 484 & 641 \\
Tmax $\left({ }^{\circ} \mathrm{C}\right)$ & $<440$ & $<440$ & $<440$ & $<440$ & $<440$ \\
Depth $(\mathrm{m})$ & $35-65$ & $20-65$ & $12-55$ & $15-50$ & $10-45$ \\
Thickness $(\mathrm{m})$ & 8 & 6 & 6 & 2 & 9 \\
Lithology & Black shale & Black shale & Black shale & Black shale & Black shale
\end{tabular}
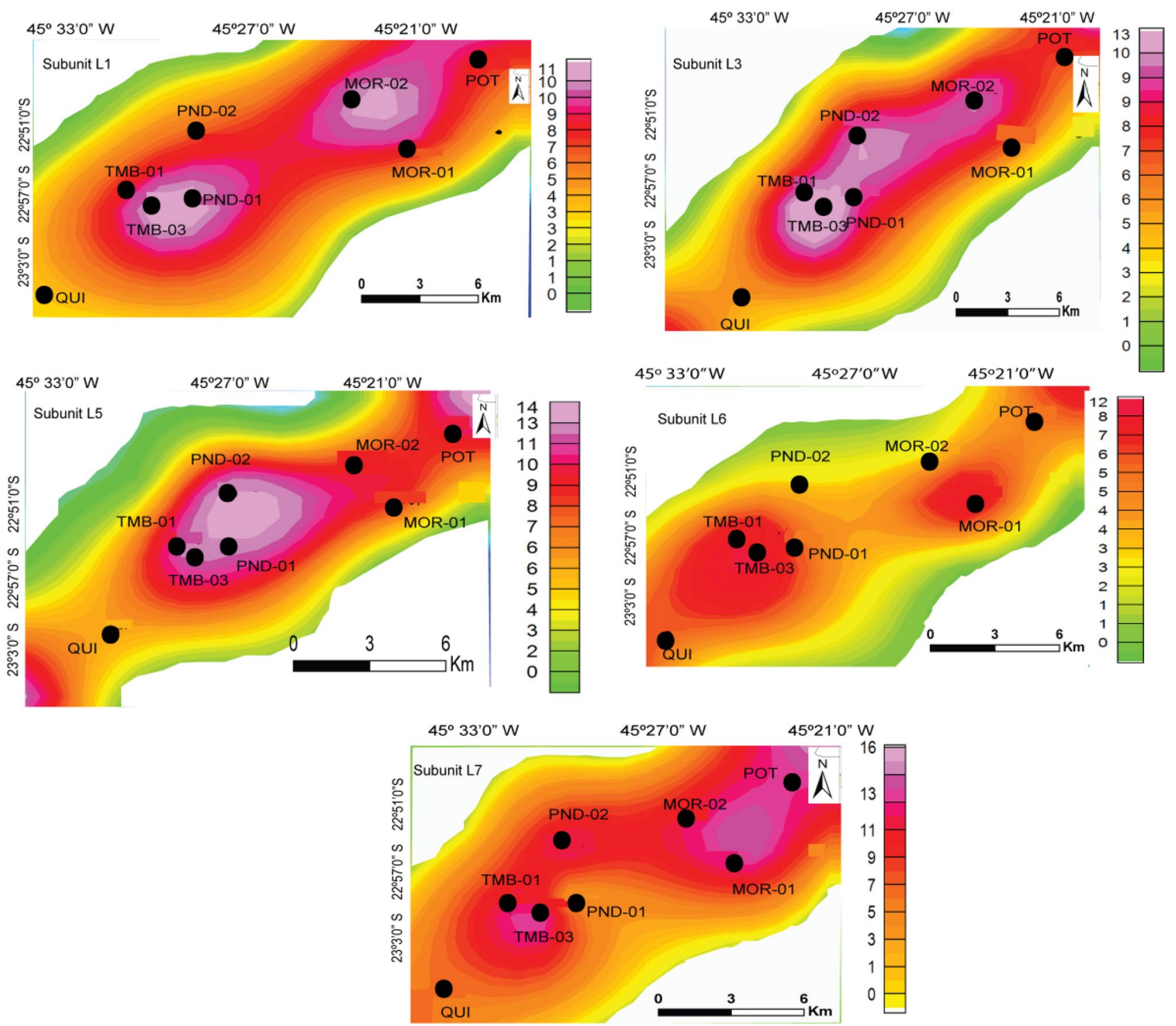

Fig. 7 Map showing the regions (wells) that are richest in TOC, for each subunit

With a cutoff yield of $100 \mathrm{mg} \mathrm{HC/g}$ rock, and with the input data regarding areas, thicknesses, densities and yields for this case, the Monte Carlo simulation resulted in an aggregated economically viable rock volume for subunits
L1, L3, L5, L6 and L7 of 1.0 billion tons of oil shale, for the P90 confidence level. For the P50 and P10 confidence levels, the economically viable rock volumes are, respectively, 1.2 billion and 1.5 billion tons of oil shale (Table 4 ). 


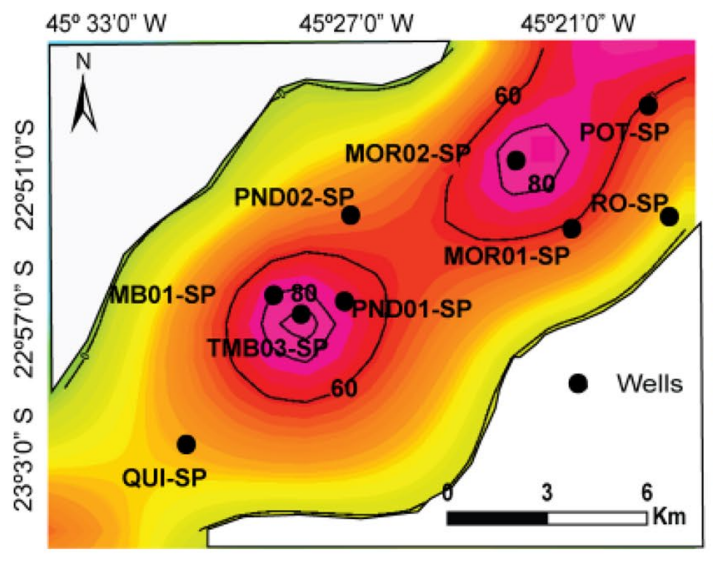

Subunit. L1

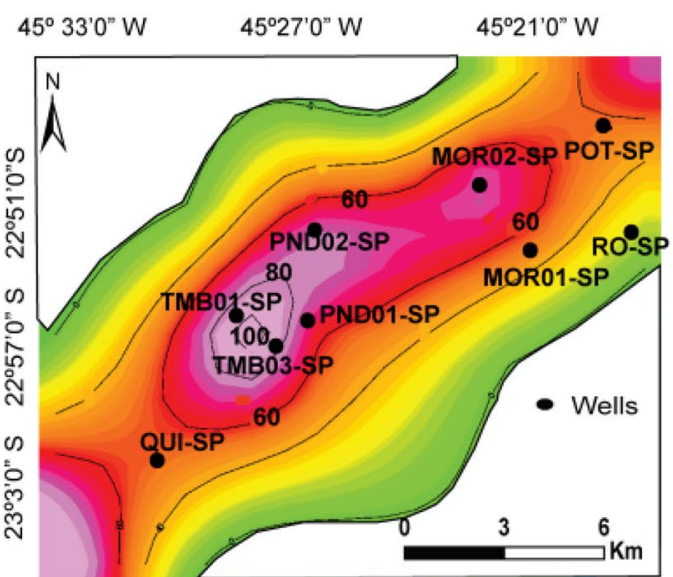

Subunit. L3
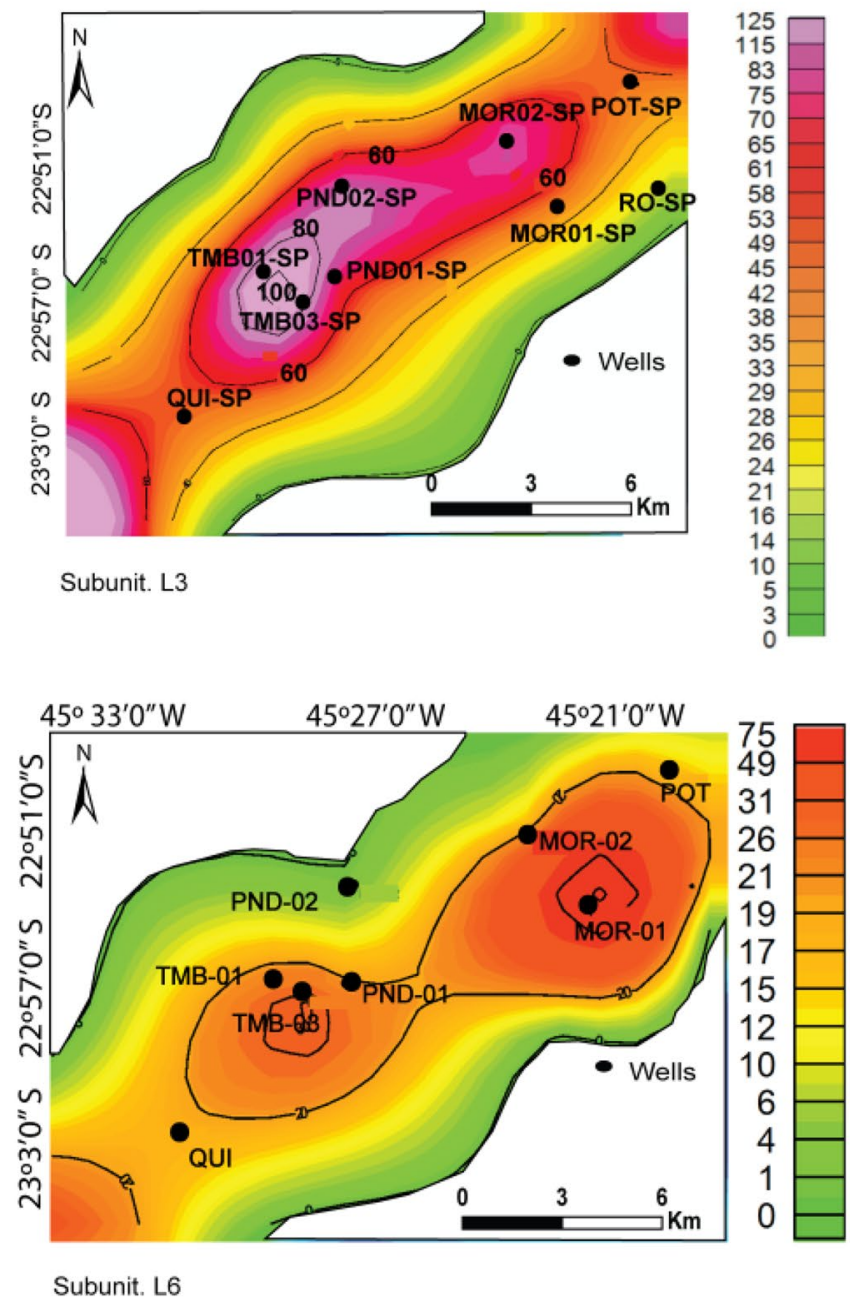

Subunit. L6
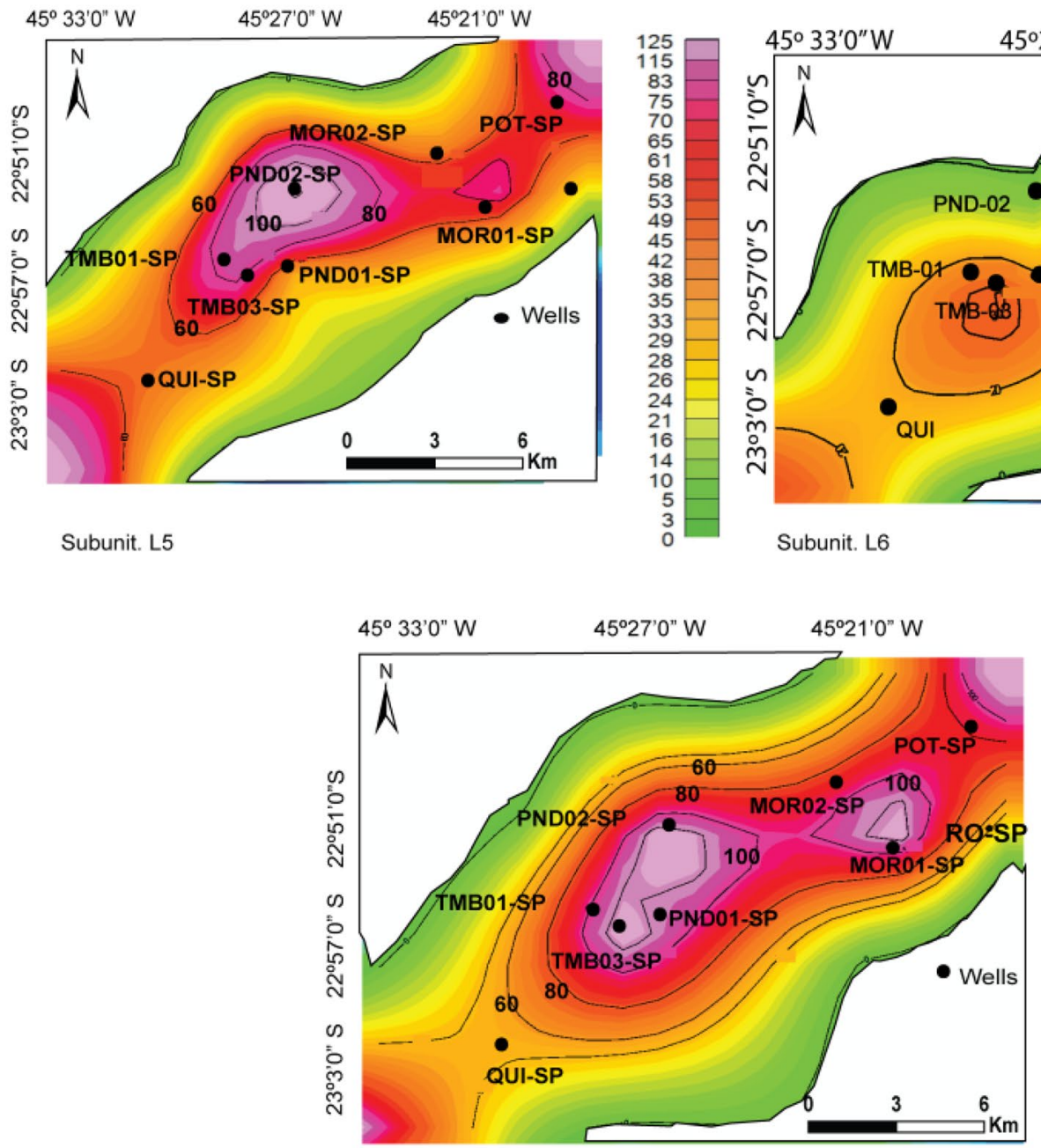

Subunit. L7

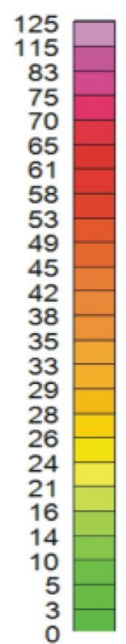

Fig. 8 Map of yield distribution $(\mathrm{S} 1+\mathrm{S} 2$, in $\mathrm{mg} \mathrm{HC} / \mathrm{g}$ rock), by subunit, utilized to estimate the average of the areas and their standard deviation. The isolines of 60,80 and $100 \mathrm{mg} / \mathrm{g}$ show the respective areas enclosed, utilized in the Monte Carlo calculations 

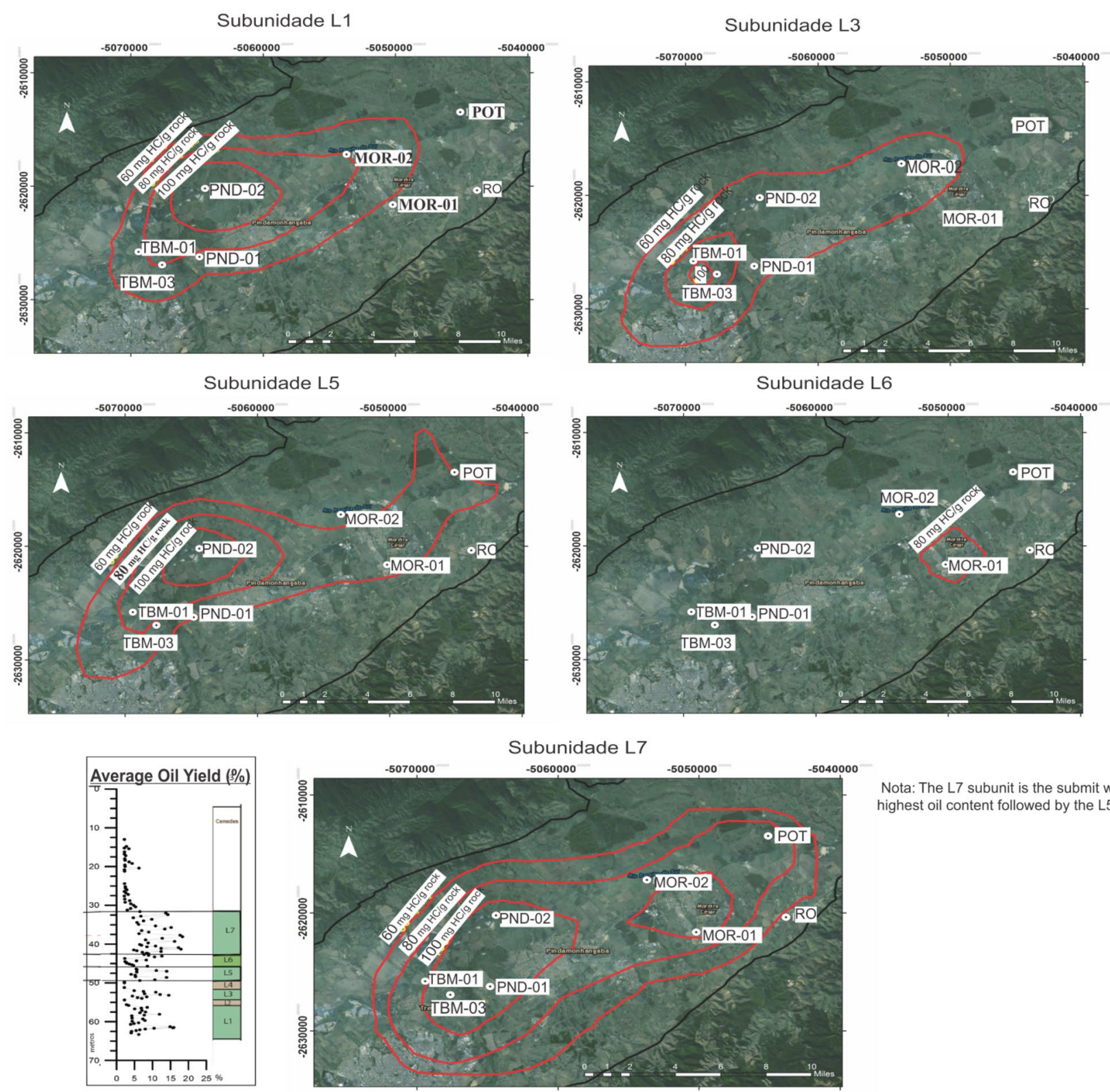

Nota: The L7 subunit is the submit with the highest oil content followed by the L5 unit

Fig. 9 The chemostratigraphic units and the isolines for yields of 60 , 80 and $100 \mathrm{mg} \mathrm{HC} / \mathrm{g}$ rock (red). It can be observed that the isolines of greatest yield (100 mg) surround wells TMB-03-SP and PND-02-SP,

For the recoverable volume of oil for those same subunits, the Monte Carlo simulation resulted in an aggregated recoverable oil volume of 525 million bbl, 686 million bbl and 884 million bbl, for the P90, P50 and P10 confidence levels, respectively.

The contribution of oil from each subunit is shown in Fig. 10, where subunit L7 stands out as the one with the greatest proportional contribution, providing approximately $89 \%$ of the total. This unit is the thickest, has the largest area and exhibits the greatest yield, in relation to the others. in most of the seven subunits, thus representing the area of greatest potential

\section{Volumetric calculation considering a yield cutoff of $80 \mathrm{mg} \mathrm{HC} / \mathrm{g}$ rock}

With a yield cutoff of $80 \mathrm{mg} \mathrm{HC/g}$ rock, and with the input data regarding areas, thicknesses, densities and yields for this case, the Monte Carlo simulation resulted in an aggregated economically viable rock volume for subunits L1, L3, L5, L6 and L7 of 3.2 billion tons, for the P90 confidence level. For the P50 and P10 confidence levels, the economically viable rock volumes are, respectively, 3.8 billion and 4.4 billion tons of oil shale (Table 5). 
Table 4 Probabilistic result for the yield cutoff of $100 \mathrm{mg} \mathrm{HC} / \mathrm{g}$ rock, considering the sum of subunits L1, L3, L5, L6 and L7

\begin{tabular}{llll}
\hline $\begin{array}{l}\text { Rock volume } \\
\text { (million tons) }\end{array}$ & \multicolumn{2}{l}{$\begin{array}{l}\text { Oil volume } \\
\text { (million } \\
\text { bbl) }\end{array}$} \\
\hline P90 & 1.0 & P90 & 525 \\
P50 & 1.2 & P50 & 686 \\
P10 & 1.5 & P10 & 884 \\
\hline
\end{tabular}

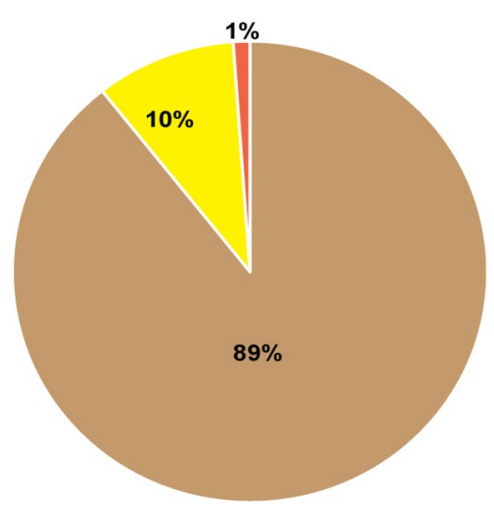

Subunit 7

Subunit 5

Subunit 3

Fig. 10 Contribution toward total oil by each subunit, for the yield cutoff of $100 \mathrm{mg} \mathrm{HC/g}$ rock

Table 5 Probabilistic result for the yield cutoff of $80 \mathrm{mg} \mathrm{HC} / \mathrm{g}$ rock, considering the sum of subunits L1, L3, L5, L6 and L7

\begin{tabular}{lrlr}
\hline $\begin{array}{l}\text { Rock volume } \\
\text { (billion tons) }\end{array}$ & \multicolumn{2}{l}{$\begin{array}{l}\text { Oil volume } \\
\text { (billion } \\
\text { bbl) }\end{array}$} \\
\hline P90 & 3.2 & P90 & 1.4 \\
P50 & 3.8 & P50 & 2.0 \\
P10 & 4.4 & P10 & 2.6 \\
\hline
\end{tabular}

\section{Volumetric calculation considering a yield cutoff of $60 \mathrm{mg} \mathrm{HC} / \mathrm{g}$ rock}

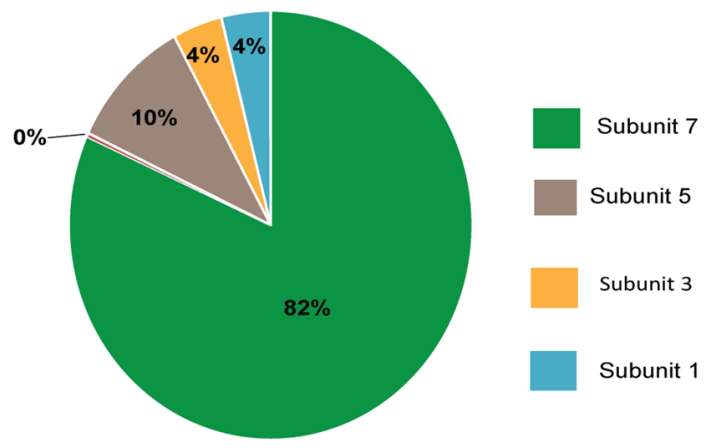

Fig. 11 Contribution toward total oil by each subunit, for the yield cutoff of $80 \mathrm{mg} \mathrm{HC} / \mathrm{g}$ rock

For the recoverable volume of oil for those same subunits, the Monte Carlo simulation resulted in an aggregated

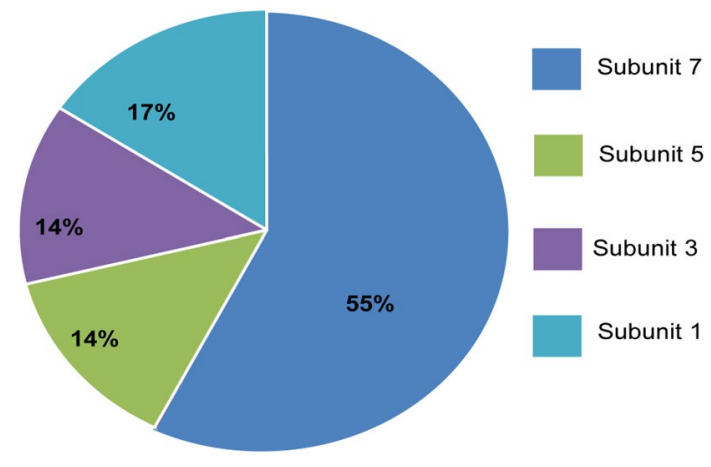

Fig. 12 Contribution toward total oil by each subunit, for the yield cutoff of $60 \mathrm{mg} \mathrm{HC} / \mathrm{g}$ rock

Table 6 Probabilistic result for the yield cutoff of $60 \mathrm{mg} \mathrm{HC/g}$ rock, considering the sum of subunits L1, L3, L5, L6 and L7

recoverable oil volume of $1.4,2.0$ and 2.6 billion bbl, for the P90, P50 and P10 confidence levels, respectively.

The contribution of oil from each subunit is shown in Fig. 11, where subunit L7 again stands out as the one with the greatest proportional contribution, providing approximately $82 \%$ of the total (Table 6).

A third scenario was utilized, which considered the possibility of exploiting oil shale layers with average cutoff yields of $60 \mathrm{mg} \mathrm{HC} / \mathrm{g}$ rock. With this cutoff yield, and with the input data regarding areas, thicknesses, densities and yields for this case, the Monte Carlo simulation resulted in an aggregated economically viable rock volume for subunits L1, L3, L5, L6 and L7 of 8.1 billion tons, for the P90 confidence level. For the P50 and P10 confidence levels, the economically viable rock volumes are, respectively, 9.3 billion and 10.6 billion tons of oil shale (Table 6).

For the recoverable volume of oil for those same subunits, the Monte Carlo simulation resulted in an aggregated recoverable oil volume of 3.6, 4.5 and 5.4 billion bbl, for the P90, P50 and P10 confidence levels, respectively.

The contribution of oil from each subunit is shown in Fig. 12, where subunit L7 once again stands out as the one with the greatest proportional contribution, providing approximately $55 \%$ of the total. 
The volumetric calculations showed that subunits L7 and L5 contribute the most toward the total recoverable volume of oil in the three scenarios studied. In Fig. 8, it can be seen that those two subunits exhibit the highest potential for oil shale between wells PND-02-SP and TMB-03-SP.

\section{Conclusions}

The upper section of Tremembé Formation, involving an interval approximately $240 \mathrm{~m}$ thick, was subdivided into 13 chemostratigraphic units, informally named A to $\mathrm{M}$, from the base to the top. Unit L, approximately $35 \mathrm{~m}$ thick, represents the interval with the greatest organic matter enrichment; thus, from a hydrocarbon generation point of view, it holds the most interest. This unit was further subdivided into seven subunits, of which five exhibit the greatest exploratory attractiveness: L1, L3, L5, L6 and L7. Among these, subunits L5 and L7 exhibit a high yield factor. For subunit L7 the yield is highest at wells TMB-03-SP, PND-02-SP and MOR-01-SP, and for subunit L5 the yield is highest at well PND-02-SP. In the areas next to the edge of the basin, such as in wells QUI-01-SP, RO-01-SP and POT-01-SP, the yield factors tend to be smaller; thus, they represent areas of low economic interest.

Considering the three scenarios investigated for subunits L1, L3, L5, L6 and L7, the one that considers only the areas that exhibit the highest yield (minimum cutoff yield of $100 \mathrm{mg} \mathrm{HC} / \mathrm{rock}$ ) indicates significant recoverable oil resources of approximately 525, 686 and 884 million bbl, for confidence levels of P90, P50 and P10, respectively. An intermediary scenario with minimum cutoff yield of $80 \mathrm{mg}$ $\mathrm{HC} /$ rock indicates substantial recoverable oil resources of approximately 1.4, 2.0 and 2.6 billion bbl, for confidence levels of P90, P50 and P10, respectively. Finally, a more optimistic scenario that considers the possibility of exploiting oil shale layers with average cutoff yields of $60 \mathrm{mg} \mathrm{HC} / \mathrm{g}$ rock, indicates very substantial recoverable oil resources of 3.6, 4.5 and 5.4 billion bbl, for confidence levels of P90, $\mathrm{P} 50$ and P10, respectively. Thus, the volumetric calculations performed utilizing Monte Carlo simulations indicate the existence of significant amounts of hydrocarbons that can be recovered from the oil shale, by applying industrial recovery methods to the most enriched levels.

Acknowledgements To the Oil and Gas NIST (National Institutes of Science and Technology)-Unconventional Resources-INOG (CNPq. FAPERJ. proc. E-26/170.026/2009) and the Project "REDE GASBRAS" (Financiadora de Estudos e Projetos-Finep), for the financial support to carry out drilling and field work, as well as the analytical phases. To the LGQM (Laboratory of Chemostratigraphy and Organic Geochemistry) and its technical staff, for the geochemical analyses. And to UERJ, for its institutional support. Fernanda Setta also thanks FAPERJ for her Doctoral Scholarship. Marco Brito also thanks Finep and FUSP for his research scholarship, in the Project "REDE GASBRAS."

Open Access This article is licensed under a Creative Commons Attribution 4.0 International License, which permits use, sharing, adaptation, distribution and reproduction in any medium or format, as long as you give appropriate credit to the original author(s) and the source, provide a link to the Creative Commons licence, and indicate if changes were made. The images or other third party material in this article are included in the article's Creative Commons licence, unless indicated otherwise in a credit line to the material. If material is not included in the article's Creative Commons licence and your intended use is not permitted by statutory regulation or exceeds the permitted use, you will need to obtain permission directly from the copyright holder. To view a copy of this licence, visit http://creativecommons.org/licenses/by/4.0/.

\section{References}

Abreu SF (1936) Rochas Oleígenas do Brasil e seu aproveitamento. Ministério do Trabalho Indústria Comércio. Instituto Nacional de Tecnologia, Rio de Janeiro

Bergamaschi S, Rodrigues R, Pereira E (2010) Avaliação Geoquímica dos folhelhos betuminosos da Formação Tremembé, Bacia de Taubaté, Brasil. Memorias - Museu e Laboratorio Mineralogico e Geologico, Faculdade de Ciencias, Universidade do Porto, vol 14. pp 263-272

Campos JM (1952) Os depósitos de folhelho betuminoso da Bacia do Paraíba e o problema de sua mineração I. A jazida pirobetuminosa do Vale do Paraíba. Engenharia de Mineração, Metetalurgia, São Paulo. 16(96):417-421

Castro E, Silva EM (1952) Xistos oleígenos do Vale do Paraíba do Sul e sua industrialização. Almeida Marques, Rio de Janeiro: Gráfica, p 137

Chagas RBA, Mendonça Filho JG, Mendonça JO, Menezes TR (2009) Caracterização Palinofaciológica de uma sucessão sedimentar Oligocênica da Formação Tremembé. Bacia de Taubaté. Rev. Bras. Paleontol. 12(3):257-266

Duarte FS (2012) Avaliação do potencial gerador da Formação Tremembé, Bacia de Taubaté, área de Pindamonhangaba e Moreira César, SP. 2012. Dissertação (Mestrado-Programa de PósGraduação em Análise de Bacias e Faixas Móveis)—Universidade do Estado do Rio de Janeiro/RJ

Dyni JR (2006) Geology and resources of some world oil-shale deposits. U.S. Geological Survey Scientific Investigations Report 2005-5294, p 42

Espistalié J, Deroo G, Marquis F (1985) La pyrolyse Rock-Eval et ses applications-première/deuxième partie. Revue de l'Institute Français du Petrole. 40(56):563-579

Fernandes FL (1993) Compartimentação Tectônica e Evolução da Bacia de Taubaté. Dissertação de Mestrado apresentada à Escola de Minas da Universidade Federal de Ouro Preto, p 145

Freitas MS (2007) Estratigrafia de Alta Resolução e Geoquímica Orgânica da Formação Tremembé. Terciário da Bacia de Taubaté. Região de Taubaté-Tremembé - SP. Universidade do Estado do Rio de Janeiro. Faculdade de Geologia. Rio de Janeiro. Dissertação de Mestrado (inédito), p 80

Jones CM (2009) Aplicação do conceito de área exaurida à região de águas rasas da bacia petrolífera de Campos, utilizando ferramentas de modelagem do processo exploratório. 141 f. Dissertação (Mestrado). Universidade do Estado do Rio de Janeiro. Rio de Janeiro

Lima MR, Salard-Cheboldaeff M, Suguio K (1985) Étude palynologique de la Formation Tremembé. Tertiaire du Bassin de Taubaté (État de São Paulo. Brésil). d'apres lês echantillons

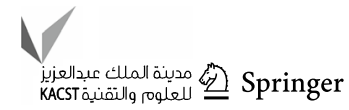


du sondage n-42 du CNR In: COLETÂNEA de trabalhos paleontológicos. Brasília. DNPM, pp 379-393. (Série Geologia. 27. Seção Paleontologia e Estratigrafia. 2)

Marques A (1990) Evolução tectono-sedimentar e perspectivas exploratórias da Bacia de Taubaté, SP, Brasil. Boletim de Geociências da Petrobrás 4(3):253-262

Mendonça Filho J et al (2010) Organic facies of the Oligocene lacustrine system in the Cenozoic Taubaté basin, Southern Brazil. Int J Coal Geol 84:166-178. https://doi.org/10.1016/j.coal.2010.07.004

Mezzalira S (1989) Os Fósseis do Estado de São Paulo: IGG. Série Pesquisa, São Paulo, p 155

Milani EJ, Araújo LM (2003) Recursos Minerais Energéticos: Petróleo. In: Bizzi LA, Schobbenhaus C, Vidotti RM, Gonçalves JH (eds) Geologia Tectônica e Recursos Minerais do Brasil. CPRM, Brasília, pp 541-577

Milani E, França AB, Medeiros RA (2007) Roteiros Geológicos, Rochas geradoras e rochas reservatório da Bacia do Paraná. Boletim de Geociências da Petrobras 15:135-162

Padilha AL, Trivedi NB, Vitorello I, Costa JM (1991) Geophysical constraints on tectonic models of the Taubaté Basin, southeastern Brazil. Tectonophysics 196:157-172

Padula VT (1969) Oil shale of permian iratí formation, Brazil. Am Assoc Pet Geol Bullet 53(3):591-602

Riccomini C (1989) O Rift Continental do Sudeste do Brasil. Inst. de Geociências. Universidade de São Paulo. São Paulo. Tese de Doutorado, p 256

Riccomini C, Sant’anna LG, Ferrari AL (2004) Evolução geológica do Rift Continental do Sudeste do Brasil. In: Mantesso-Neto V, Bartorelli A, Dal Ré Carneiro C, Brito Neves BB (eds) Geologia do Continente Sul-Americano: Evolução da Obra de Fernando Flávio Marques de Almeida. São Paulo, Editora Beca, pp 383-405

Sampol JFG (2007) Estratigrafia de alta resolução da Formação Tremembé (Oligoceno, Bacia de Taubaté) em poços de sondagem. Monografia Final de Conclusão de Curso. Departamento de Geologia. Universidade Federal do Rio de Janeiro, p 47

Setta F, Bergamaschi S, Rodrigues R, Pereira E, Chaves HAF (2012) Avaliação de Jazidas Não Convencionais: Folhelhos Betuminosos da Formação Tremembé, Bacia de Taubaté. In: RIO OIL and GAS. Rio de Janeiro. Technical Papers

Silva FANG (2007) Estudos de Caracterização Tecnológica e Beneficiamento do Caulim da Região Borborema-Seridó. 2007. 70 f. Dissertação (Mestrado). Rio de Janeiro: COPPE/UFRJ.2007

Soldan AN, Neto EVS, Cerqueira JR, Concha FJM, Castelo Branco VA, Arai M (1988) Hidropirólise: Uma nova ferramenta para o estudo do processo de maturação. Boletim de Geociências da Petrobras, Rio de Janeiro. 2(1):65-76

SPE-PRMS (2007) SPE/WPC/AAPG/SPEE Petroleum resources management system. SPE

Suguio K (1969) Contribuição à geologia da Bacia de Taubaté. Vale do Paraíba, estado de São Paulo. Boletim da Faculdade de Filosofia. Ciências e Letras da Universidade de São Paulo

Torres-Ribeiro M (2004) Fácies microclásticas de um sistema lacustre oligocênico do sudeste do Brasil (Formação Tremembé, bacia de Taubaté). Universidade Federal do Rio de Janeiro. Instituto de Geociências. Rio de Janeiro. Dissertação de Mestrado, p 122

Torres-Ribeiro ML, Borghi L (2007) O uso de microfácies sedimentares na caracterização de potenciais rochas geradoras de um sistema lacustre paleogênico na Bacia de Taubaté. Proceedings of $4^{\circ}$ PDPETRO_Congresso Brasileiro de P\&D em Petróleo e Gás, ABPG. Campinas. Brazil

Vidal AC, Fernandes FL, Chang HK (2004) Distribuição dos arenitos na bacia de Taubaté -SP. São Paulo. UNESP. Geociências 23(1/2):55-66

Zalán PV, Oliveira JAB (2005) Origem e evolução estrutural do Sistema de Riftes Cenozóicos do Sudeste do Brasil. Boletim. Geociências. Petrobrás 13(2):269-300

Publisher's Note Springer Nature remains neutral with regard to jurisdictional claims in published maps and institutional affiliations. 